Journal of Clinical Investigation

Vol. 42, No. 2, 1963

\title{
THE RATE OF FORMATION AND LYMPHATIC REMOVAL OF FLUID IN PLEURAL EFFUSIONS
}

\author{
By P. B. STEWART \\ (From the Joint Cardiorespirator Service of the Royal Victoria Hospital and Montreal \\ Children's Hospital, McGill University, Montreal, Que.)
}

(Submitted for publication June 22, 1962; accepted November 1, 1962)

Courtice and Simmonds (1) have shown the importance of lymphatic drainage from the serous cavities. They showed that protein labeled with T-1824 and injected into the pleural cavity in cats is removed exclusively by the lymphatic vessels. The rate of removal of labeled protein from the pleural cavity therefore is a measure of lymphatic flow. Burgen and Stewart (2) described a method for measuring the rate of formation and removal of protein-containing fluid from the pleural cavity in dogs.

In the present paper, a method of measuring the average lymphatic flow of fluid out of the pleural cavity and the net fluid entry into the pleural cavity is described. This method afforded an opportunity to measure the rates of formation and removal of protein-containing fluid in established pleural effusions of varying etiology in man.

\section{METHODS}

Patients with proved pleural effusions were included in this study. The patients were unselected as to the cause of their effusion or length of stay in hospital, but most were studied soon after admission. The study was done at the time of the diagnostic thoracentesis.

A thoracentesis was performed under a local anesthetic with a no. 14 needle. A Clay Adams PE 90 catheter was introduced through the needle, which was then withdrawn, and the outer end of the catheter was occluded by a spigot. The pleural catheter was fixed to the chest wall by collodion and adhesive tape, and covered by a dressing. After control samples of pleural fluid were taken, a measured amount of $\mathrm{T}-1824^{1}$ that had been mixed with about $5 \mathrm{ml}$ of withdrawn pleural fluid was injected through the catheter from a calibrated syringe. $\mathrm{T}-1824$ binds firmly to plasma albumin present in the pleural fluid. The amount of dye removed is then a measure of the amount of protein-containing fluid absorbed by the lymphatics from the pleural cavity. The dilution of the dye concentration in the effusion is a measure of the entry of new fluid into the pleural cavity. The dye was mixed in the pleural cavity by withdrawal and reinjection of pleural fluid through the catheter for

\footnotetext{
1 Warner-Chilcott Laboratories, Morris Plains, N. J.
}

5 to 10 minutes. Samples of pleural fluid containing the dye were taken at regular intervals. Most patients were studied for 24-hour periods divided into two parts, one a waking period during the day and the other period overnight. None of the procedures was followed by any untoward effects.

Syringes were previously coated with silicone (Beckman-Desicote). All apparatus was autoclaved except the polyethylene catheter, which was sterilized by boiling in water for 10 minutes.

Estimations of $T-1824$, protein, and para-aminohippuratc. T-1824 in the pleural fluid was estimated by the acetone extraction method of Chinard (3), and the absorption read at $620 \mathrm{~m} \mu$ in a Beckman DU spectrophotometer. The protein concentration of the pleural fluid and blood plasma was measured by the biuret method of Robinson and Hogden (4), and the absorption read at $650 \mathrm{~m} \mu$. Para-aminohippurate was estimated by the method of Smith and co-workers (5), and the absorption read at $540 \mathrm{~m} \mu$.

Theoretical considerations. The basis of the present method is the assumption that protein labeled with T-1824 is removed solely by the lymphatic vessels and in the concentration present in the pleural fluid. The amount removed in the course of an experiment is then a measure of the lymphatic flow from the pleural cavity. The rate of entry of new fluid from the pleural capillaries shown by a change in concentration of the T-1824 in the pleural fluid is then a measure of net fluid entry. It is clear that the movement of fluid shown by this method is a bulk flow, since it is envisaged that there is an internal circulation wherein protein-containing fluid formed from the pleural capillaries crosses the pleural space to be absorbed at a different site by the pleural lymphatic vessels.

Four assumptions of the method are discussed as follows.

1) There is no direct evidence to prove the assumption that humans remove all the proteins in the pleural fluid by the lymphatic vessels, but there is experimental evidence in animals to support it. Courtice and Simmonds (1) showed in cats that T-1824-labeled plasma failed to enter the circulating blood from the pleural cavity after the thoracic duct and right lymphatic duct had been tied, and that high concentrations of the dye were found in the lymphatic vessels when they were cannulated.

2) The protein concentration (and also the T-1824 concentration) in lymph leaving the pleural space is as- 
sumed to be identical with that in the pleural fluid. In other words, the pleural fluid is not subjected to any ultrafiltration while entering the lymphatic vessels. Stewart and Burgen (6) fully discussed this question in describing fluid movements in the pleural space of dogs. The points against ultrafiltration of pleural fluid as it enters the lymphatic vessels are as follows. a) Large particles such as red and white blood cells leave the pleural cavity in the lymphatic vessels, which are, in fact, adapted for the very purpose of removing substances of large molecular weight, particulate matter and cells. If the pore size of the lymphatic vessels can admit these, it is hardly conceivable that there could be any sieving effect of molecules the size of protein. $b$ ) If the lymphatic vessels were the site of ultrafiltration, there would have to be a force to draw fluid into them against the partial osmotic pressure created by the holding back of protein. This force would necessitate a pressure lower than in the pleural cavity, and since the lymphatic vessels are not a rigid system, such a pressure difference could not be established.

3) In the course of these experiments, no T-1824 was ever detected in the circulating blood, and therefore there was no error from re-entry of T-1824.

4) T-1824 is assumed to be bound exclusively and completely to pleural fluid protein, and so traces this protein. Burgen and Stewart (2) checked this point in previous experiments in dogs; they confirmed that T-1824 and $\mathrm{I}^{131}$-albumin gave identical results, so there could not be any error due to the binding of $\mathrm{T}-1824$ to the pleura. The concentration of $\mathrm{T}-1824$ used in dogs was some 10 to 20 times higher than in the present study in humans, so that there would be any binding of T-1824 to the pleura is unlikely, but was not specifically checked.

In the course of a typical experiment, the concentration of $\mathrm{T}-1824$ in the pleural fluid was plotted against time. A line determined by the method of least squares was drawn and the concentration at zero time determined (Figure 1). The volume of pleural fluid at zero time was calculated by Equation $1, V=A / C$, where $V=$ volume of pleural fluid, $A=$ milligrams T-1824, and $C=$ concentration of T-1824 in pleural fluid. After 6 to 8 hours, or 16 to 18 hours in the overnight studies, more $\mathrm{T}-1824$ was injected into the pleural fluid, and after mixing, samples were withdrawn every 30 minutes for 2 hours (Figure 1). The volume of pleural fluid was recalculated by Equation 1, taking into account the rise in concentration produced by the injected T-1824.

The amount of dye $Q$ removed by the lymphatic vessels in the course of the experiment can then be calculated by Equation 2, $Q=\left[\left(V_{t_{0}} \times C_{t_{0}}\right)-\left(V_{t_{1}} \times C_{t_{1}}\right)\right]-$ $\Sigma S$, where $S=$ milligrams $\mathrm{T}-1824$ withdrawn in samples. The volume in milliliters of pleural fluid removed per hour, or the lymphatic flow $L$, is given by Equation 3, $L=Q / C_{m} \times 1 / t$, where $C_{m}=$ mean concentration of $\mathrm{T}-1824$ in pleural fluid (the half-time point) and $t=$ time in hours. The volume in milliliters of fluid entering the pleural cavity per hour, or the nonlymphatic flow $E$, is determined by Equation 4, $E=\left[\left(V_{t_{1}}-V_{t_{0}}\right) / t\right]+\Sigma_{m}+L$,

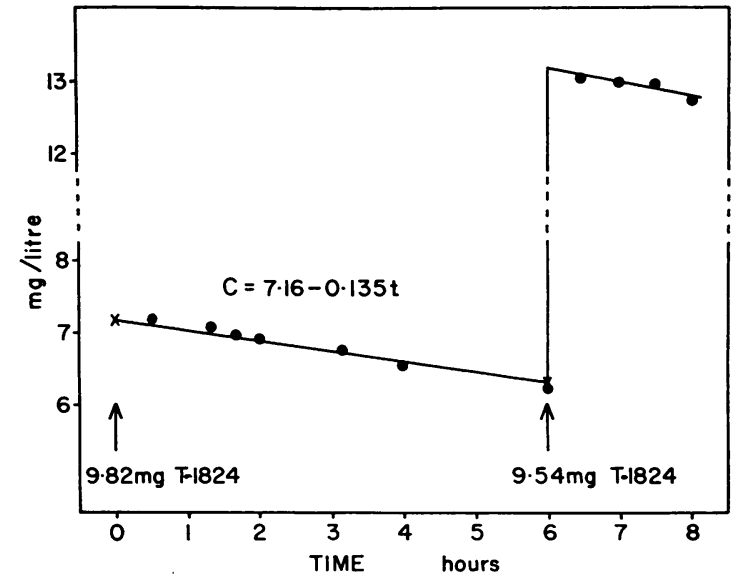

Fig. 1. Concentration of T-1824 in pletral fluid PLOTTED AGAINST TIME IN HOURS IN A TYPICAL EXPERIMENT. After injection of T-1824, concentration fell linearly with time. The slope of the line was determined by the method of least squares and extrapolated to determine the concentration at zero time and from this, the volume of pleural fluid at the beginning of the experiment. After 6 hours, a further injection of T-1824 resulted in a rise in concentration. Samples taken every 30 minutes over the next 2 hours allowed for complete mixing and the slope of the line to be determined. By extrapolation, concentration and hence volume at the time of the injection were found.

where $\Sigma_{m}=$ total volume in milliliters of samples withdrawn and $t=$ time in hours. For comparison, results were expressed as milliliters per kilogram per hour by dividing the rates of lymphatic flow $L$ and nonlymphatic flow $E$ by the patient's weight in kilograms.

\section{RESULTS}

Eleven patients were studied; one patient was studied on two occasions 1 week apart. The details for each patient are given in Table I. The average fluid outflow from the pleural cavity, or the lymphatic flow, was $0.364 \pm 0.156$ (SD) $\mathrm{ml}$ per $\mathrm{kg}$ per hour, and the rate of fluid entry, or the nonlymphatic flow, was $0.395 \pm 0.236$ (SD) $\mathrm{ml}$ per $\mathrm{kg}$ per hour. These rates are about half the comparable ones found by Stewart and Burgen (6) in dogs, but the discrepancy could be explained by the separation of pleural cavities in man, whereas in dogs there is free communication between the two sides.

The over-all turnover rates of pleural fluid in both groups showed there was a higher rate of fluid entry into the pleural cavity than fluid outflow, so that the volume of the pleural effusion 
TABLE I

Data for patients studied*

\begin{tabular}{|c|c|c|c|c|c|c|c|c|c|}
\hline \multirow[b]{2}{*}{ Patient } & \multirow[b]{2}{*}{ Sex } & \multirow[b]{2}{*}{ Age } & \multirow[b]{2}{*}{ Weight } & \multirow[b]{2}{*}{ Diagnosis $\ddagger$} & \multirow{2}{*}{$\begin{array}{c}\text { Fluid } \\
\text { outflow } \\
\text { from } \\
\text { pleural } \\
\text { cavity } \\
\text { (lymphatic) }\end{array}$} & \multirow{2}{*}{$\begin{array}{l}\text { Fluid } \\
\text { entry } \\
\text { into } \\
\text { pleural } \\
\text { cavity } \\
\text { (nonlym- } \\
\text { phatic) }\end{array}$} & \multirow[b]{2}{*}{$\begin{array}{l}\text { Volume } \\
\text { of fluid }\end{array}$} & \multicolumn{2}{|c|}{$\begin{array}{c}\text { Protein concentra- } \\
\text { tion }\end{array}$} \\
\hline & & & & & & & & $\begin{array}{l}\text { Blood } \\
\text { plasma }\end{array}$ & $\begin{array}{c}\text { Pleural } \\
\text { fluid }\end{array}$ \\
\hline & & years & $k g$ & & $\mathrm{ml} / \mathrm{kg} / \mathrm{hr}$ & $\mathrm{ml} / \mathrm{kg} / \mathrm{hr}$ & $m l$ & \multicolumn{2}{|c|}{$\mathrm{g} / 100 \mathrm{ml}$} \\
\hline Hp & $\mathbf{F}$ & 23 & 44.5 & $\mathrm{CHF}$ & 0.50 & 0.55 & 530 & 8.6 & 3.80 \\
\hline $\mathbf{B a}$ & $\mathbf{M}$ & 64 & 73.0 & CHF & 0.25 & 0.39 & 1,370 & 9.0 & 2.90 \\
\hline $\mathbf{Y a}$ & $\mathbf{M}$ & 71 & 62.3 & $\mathrm{CHF}$ & 0.36 & 0.29 & 1,061 & 7.0 & 3.36 \\
\hline Mo & $\mathrm{F}$ & 53 & 71.4 & $\mathrm{CHF}$ & 0.16 & 0.10 & 988 & 7.8 & 2.24 \\
\hline El & $\mathbf{M}$ & 70 & 75.5 & $\mathrm{CHF}$ & 0.66 & 0.40 & 1,389 & & 2.98 \\
\hline $\mathrm{Ga}$ & $\mathbf{M}$ & 63 & 55 & CHF & 0.38 & 0.23 & 798 & 8.1 & 3.00 \\
\hline Cht & $\mathbf{M}$ & 64 & 54.5 & $\mathrm{CHF}$ & $\begin{array}{l}0.43 \\
0.52\end{array}$ & $\begin{array}{l}0.93 \\
0.55\end{array}$ & $\begin{array}{r}1,200 \\
946\end{array}$ & 7.7 & 2.98 \\
\hline Gr & $\mathbf{F}$ & 83 & 54.5 & $\begin{array}{l}\text { Carcinoma } \\
\text { of bronchus }\end{array}$ & 0.30 & 0.35 & 1,687 & 7.83 & 4.64 \\
\hline Gn & $\mathbf{M}$ & 58 & 69.0 & Nephrosis & 0.44 & 0.08 & 860 & 6.00 & 1.75 \\
\hline $\mathrm{Br}$ & $\mathbf{M}$ & 18 & 95.5 & Tuberculosis & 0.21 & 0.32 & 1,037 & & \\
\hline $\mathbf{B z}$ & $\mathbf{F}$ & 45 & 100.6 & $\begin{array}{l}\text { Carcinoma } \\
\text { of ovary }\end{array}$ & 0.16 & 0.57 & 2,260 & 7.9 & 5.2 \\
\hline Mean & & 55.6 & 68.71 & & 0.364 & 0.395 & $1,177.2$ & 7.77 & 3.28 \\
\hline SD & & \pm 20.09 & \pm 17.39 & & \pm 0.156 & \pm 0.236 & \pm 456.9 & \pm 0.27 & \pm 1.04 \\
\hline
\end{tabular}

* There was no correlation between volume of pleural fluid and rates of fluid outflow or entry. $\dagger$ Studied on two separate occasions.
I $\mathrm{CHF}=$ congestive heart failure.

was increasing slowly. This was expected be- of pleural fluid was some 10 to 12 times faster than cause the patients were studied immediately after the change in pleural fluid volume, meaning that their admission to the hospital and before treat- approximately 650 to $700 \mathrm{ml}$ of pleural fluid would ment had had time to be effective. The turnover be formed and absorbed in 24 hours in a patient

TABLE II

Diurnal variation in rates of lymphatic and nonlymphatic flow

\begin{tabular}{|c|c|c|c|c|c|c|c|c|}
\hline \multirow[b]{2}{*}{ Patient } & \multirow[b]{2}{*}{ Sex } & \multirow[b]{2}{*}{ Age } & \multirow[b]{2}{*}{ Weight } & \multirow[b]{2}{*}{ Diagnosis* } & \multicolumn{2}{|c|}{ During day } & \multicolumn{2}{|c|}{ During night } \\
\hline & & & & & $\begin{array}{l}\text { Fluid } \\
\text { outflow } \\
\text { (lym- } \\
\text { phatic) }\end{array}$ & $\begin{array}{c}\text { Fluid } \\
\text { entry } \\
\text { (nonlym- } \\
\text { phatic) }\end{array}$ & $\begin{array}{c}\text { Fluid } \\
\text { outflow } \\
\text { (lym- } \\
\text { phatic) }\end{array}$ & $\begin{array}{c}\text { Fluid } \\
\text { entry } \\
\text { (nonlym- } \\
\text { phatic) }\end{array}$ \\
\hline $\mathrm{Ch}$ & M & $\begin{array}{l}\text { years } \\
64\end{array}$ & $\begin{array}{l}\mathrm{kg} \\
54.5\end{array}$ & $\mathrm{CHF}$ & $\begin{array}{c}\mathrm{ml} / \mathrm{kg} / \mathrm{hr} \\
0.52\end{array}$ & $\begin{array}{c}\mathrm{ml} / \mathrm{kg} / \mathrm{hr} \\
0.55\end{array}$ & $\begin{array}{c}\mathrm{ml} / \mathrm{kg} / \mathrm{hr} \\
0.20\end{array}$ & $\begin{array}{c}m l / k g / h r \\
0.27\end{array}$ \\
\hline $\mathrm{Ei}$ & $\mathbf{M}$ & 70 & 75.5 & $\mathrm{CHF}$ & 0.66 & 0.40 & 0.51 & 0.26 \\
\hline Mo & $\mathrm{F}$ & 53 & 71.4 & $\mathrm{CHF}$ & 0.16 & 0.10 & 0.26 & 0.15 \\
\hline $\mathrm{Ya}$ & M & 71 & 62.3 & $\mathrm{CHF}$ & 0.36 & 0.29 & 0.18 & 0.21 \\
\hline $\mathrm{Ba}$ & $\mathbf{M}$ & 64 & 73.0 & $\mathrm{CHF}$ & 0.25 & 0.39 & 0.14 & 0.30 \\
\hline $\mathrm{Hp}$ & $\mathrm{F}$ & 23 & 44.5 & $\mathrm{CHF}$ & 0.50 & 0.55 & 0.21 & 0.27 \\
\hline $\mathrm{Gr}$ & $\mathrm{F}$ & 83 & 54.5 & $\begin{array}{l}\text { Carcinoma } \\
\text { of bronchus }\end{array}$ & 0.30 & 0.35 & 0.23 & 0.14 \\
\hline $\mathrm{Bz}$ & $\mathrm{F}$ & 45 & 100.6 & $\begin{array}{l}\text { Carcinoma } \\
\text { of ovary }\end{array}$ & 0.16 & 0.57 & 0.07 & 0.25 \\
\hline $\mathrm{Gn}$ & $\mathbf{M}$ & 58 & 69.0 & Nephrosis & 0.44 & 0.08 & 0.10 & 0.11 \\
\hline $\begin{array}{l}\text { Mean } \\
\text { SD }\end{array}$ & & $\begin{array}{l}59.0 \\
17.36\end{array}$ & $\begin{array}{l}67.3 \\
15.94\end{array}$ & & $\begin{array}{l}0.37 \\
0.18\end{array}$ & $\begin{array}{l}0.35 \\
0.21\end{array}$ & $\begin{array}{l}0.21 \\
0.12\end{array}$ & $\begin{array}{l}0.22 \\
0.03\end{array}$ \\
\hline
\end{tabular}

* $\mathrm{CHF}=$ congestive heart failure. 
TABLE III

Clearance of para-aminohippurate (PAH) from pleural fluid

\begin{tabular}{cclc}
\hline Patient & Weight & \multicolumn{1}{c}{ Diagnosis } & $\begin{array}{c}\text { PAH } \\
\text { clearance }\end{array}$ \\
\hline & $k g$ & & $\mathrm{ml} / \mathrm{kg} / \mathrm{hr}$ \\
$\mathrm{Gr}$ & 54.5 & Carcinoma of bronchus & 6.45 \\
$\mathrm{Ga}$ & 55.0 & Congestive heart failure & 3.60 \\
$\mathrm{Ei}$ & 75.5 & Congestive heart failure & 2.40 \\
$\mathrm{Ga}$ & 69.0 & Nephrosis & 6.25 \\
$\mathrm{Mo}$ & 71.4 & Congestive heart failure & 4.00 \\
Mean & 65.1 & & 4.54 \\
$\mathrm{SD}$ & \pm 9.7 & & \pm 1.75 \\
\hline
\end{tabular}

weighing $70 \mathrm{~kg}$. This represents about 20 per cent of the plasma volume per day.

There was a distinct diurnal variation in the rate of lymphatic flow and nonlymphatic flow. Nine cases were studied throughout a 24-hour period divided roughly into two parts, one a waking period during the day and the other at night when the patient was at rest and normally asleep. Fluid outflow fell from an average of $0.37 \mathrm{ml}$ per $\mathrm{kg}$ per hour during the day to 0.21 at night; fluid entry into the pleural cavity also fell, from 0.35 to $0.22 \mathrm{ml}$ per $\mathrm{kg}$ per hour. This striking diurnal fall occurred in all except one patient (Mo). Detailed results are given in Table II.

Clearance of para-aminohippurate from the pleural cavity. During the course of an experiment, 1 to $2 \mathrm{ml}$ of a 20 per cent para-aminohippurate solution was injected into the pleural effusion. Concentration fell exponentially with time and was plotted semilogarithmically. The exponential rate constant $\alpha$ was determined as $0.693 / t_{1}$, where $t_{t}$ is the time for the concentration of the para-aminohipptirate to fall by half. The clearance rate was determined by multiplying this exponential rate constant by the mean pleural fluid volume. For comparison. results were divided by the individual weights of the patients and expressed as milliliters per kilogram per hour. By these criteria, the clearance rate of para-aminohippurate from the pleural fluid averaged $4.54 \mathrm{ml}$ per $\mathrm{kg}$ per hour (Table III), or about 13 times faster than the removal of protein. The increased rate of removal of the para-aminohippurate must mean that the molecules of this size are also absorbed in large part directly into the pleural blood capillaries and are not limited by the pleural lymphatic flow.
DISCUSSION

In man, fluid is driven into the pleural cavity from the pleural blood capillaries by hydrostatic pressure, and this mechanism would be expected to conform to Starling's principles. In the pleural cavity, however, the negative pressure would be added to the capillary hydrostatic pressure. Thus an increase in negative pressure of the pleural cavity would tend to increase the amount of fluid formed. The colloidal osmotic pressure of blood plasma tends to hold fluid back in the blood capillaries. If the pleural fluid itself contains protein, this effect would be reduced proportionately. Miller (7) has shown that in man the visceral pleural capillaries are branches of the bronchial arteries and thus are derived from the systemic circulation. Fluid can therefore be present in the pleural cavity without concurrent pulmonary edema, since the alveolar capillaries are derived from the pulmonary circulation, where the hydrostatic pressures are much lower.

An internal circulation is then established whereby fluid formed from the pleural blood capillaries enters the pleural cavity and is absorbed at a different site by the pleural lymphatic vessels. This movement is applicable to protein-containing fluid. If the protein concentration of the pleural fluid is low, then water and solutes are absorbed at the venous end of the pleural blood capillaries owing to the effect of the colloidal osmotic pressure of the blood plasma. When the protein concentration in the pleural fluid rises enough, however, this hydrostatic effect will cease and the only route of absorption of pleural fluid will be by the lymphatic vessels.

Since the pleural lymphatic vessels pass through the diaphragm and intercostal muscles, movement of these structures increases flow and absorption from the pleural cavity, as was shown in unanesthetized dogs (6). The finding of the present study in humans that the rate of absorption fell significantly during the night might be explained by this in that the rate and depth of respiration is probably less at night than during the day. No definitive tests, however, were done to ascertain the mechanism. It is of great interest that the rate of formation of new pleural fluid also fell significantly during the night, but there is no immediate explanation. 
The large discrepancy between the rates of removal of a small molecule like para-aminohippurate and large protein molecules emphasizes that probably there is no holding back of solutes and water between the blood and pleural or other serous cavity effusions, and their equilibration is limited by either diffusion or blood flow. That approximately 80 per cent of the water in peritoneal effusions is exchanged every hour, as Prentice, Siri, and Joiner (8) found with a tritiumlabeled water technique, would confirm this. On the other hand, the pleural capillaries do limit the outflow of proteins, and once these have escaped from them, they can only be reabsorbed by way of the lymphatic vessels-a much slower process. There is no doubt that in clinical conditions the removal of the protein-containing fluid is the important parameter.

\section{SUMMARY}

1. A method has been described to measure the average rates of fluid outflow (lymphatic flow) and fluid entry (nonlymphatic flow) in pleural effusions in man.

2. In 11 patients studied, the fluid outflow averaged $0.364 \pm 0.156(\mathrm{SD}) \mathrm{ml}$ per $\mathrm{kg}$ per hour and the fluid entry $0.395 \pm 0.236$ (SD) $\mathrm{ml}$ per $\mathrm{kg}$ per hour.

3. Both fluid outflow and fluid entry fell significantly overnight as compared with the daytime.

4. Para-aminohippurate was removed from the pleural cavity approximately thirteen times faster than protein.

\section{ACKNOWLEDGMENTS}

The author wishes to thank Professor A. S. V. Burgen for much helpful criticism and advice with the method, and Dr. D. V. Bates for help in the preparation of the manuscript. The author also wishes to thank the members of the Medical Staff of the Royal Victoria Hospital and Montreal General Hospital for referring their cases for study.

\section{REFERENCES}

1. Courtice, F. C., and Simmonds, W. J. Absorption of fluids from the pleural cavities of rabbits and cats. J. Physiol. 1949, 109, 117.

2. Burgen, A. S. V., and Stewart, P. B. A method of measuring the turnover of fluid in the pleural and other serous cavities. J. Lab. clin. Med. 1958, 52, 118.

3. Chinard, F. P. Estimation of plasma volume by the dye dilution method in Methods in Research, M. B. Visscher, Ed. Chicago, Year Book Publishers, 1951, vol. 4, p. 38.

4. Robinson, H. W., and Hogden, C. G. The biuret reaction in the determination of serum proteins. I. A study of the conditions necessary for the production of a stable color which bears a quantitative relationship to the protein concentration. J. biol. Chem. 1940, 135, 707.

5. Smith, H. W., Finkelstein, N., Aliminosa, L., Crawford, B., and Graver, M. Renal clearance of substituted hippuric acid derivatives and other aromatic acids in dogs and man. J. clin. Invest. 1945, 24, 388.

6. Stewart, P. B., and Burgen, A. S. V. The turnover of fluid in the dog's pleural cavity. J. Lab. clin. Med. 1958, 52, 212.

7. Miller, W. S. The Lung. Springfield, Ill., Charles C Thomas, 1947.

8. Prentice, T. C., Siri, W., and Joiner, E. E. Quantitative studies of ascitic fluid circulation with tritium labelled water. Amer. J. Med. 1952, 13, 668. 